\title{
LÍRICAS CONTEMPORÂNEAS: \\ APONTAMENTOS PARA UMA REVOCALIZAÇÃO \\ DO LOGOS
}

\section{CONTEMPORARY LYRIC POEMS: \\ NOTES FOR A REVOCALIZE OF THE LOGOS}

RESUMO: Este trabalho tem o objetivo de debater o processo de emudecimento do logos poético ao longo do tempo, a partir da análise de algumas canções populares. Apoiados nas observações levadas a público por Adriana Cavarero no livro Vozes plurais: filosofia da expressão vocal (2011), investigamos a presença dos "animais vocálicos", tomando como exemplo a conhecida fábula da formiga e da cigarra de La Fontaine, passamos pelas avaliação da lírica como "voz do coração" e audição das sereias "mulheres que cantam" como signos da ontologia da poesia e da canção popular, até a polifonia vocal da mitopoética de Macunaíma, como representante de um ensaio sobre o Brasil.

PALAVRAS-CHAVE: Logos; Voz; Poesia.

\footnotetext{
${ }^{1}$ Programa de Pós-graduação em Letras, Universidade do Estado do Rio de Janeiro (UERJ), CEP: 20559-900, leonardo.davino@gmail.com. Doutorando em Literatura Comparada, bolsista FAPERJ.
} 
ABSTRACT: This paper aims at discussing the process of quieting the poetic logos over time, based on the analysis of some popular songs. Supported by the observations achieved by Adriana Cavarero in her work Vozes plurais: filosofia da expressão vocal (2011), we investigated the presence of "vowel animals", taking as example the well-known La Fontaine's fable about the ant and the grasshopper. The evolution of our research passes through the investigation of lyric poems as "voices of the heart" and the study of hearing the sirens, "singing women", as signs of the ontology of poetry and of popular song, coming to the analysis of vocal polyphony of the mythopoetic of Macunaíma as a representation of an essay about Brazil.

KEYWORDS: Logos; Voice; Poetry.

O mergulho no individuado eleva o poema lírico ao universal porque põe em cena algo de não desfigurado, de não captado, de ainda não subsumido, e desse modo anuncia, por antecipação, algo de um estado em que nenhum universal postiço, ou seja, particular em suas raízes mais profundas, acorrente o outro, o universal humano. Da mais irrestrita individuação a formação lírica tem esperança de extrair o universal. 0 risco específico que a lírica assume, entretanto, consiste em que seu princípio de individuação não garante nunca o engendramento de validade, de autenticidade. (ADORNO. Lírica e sociedade. In: Textos escolhidos. São Paulo: Abril Cultural, 1980, p.194)

"As cigarras são guitarras trágicas. / plugam-se/se/se/se / nas árvores / em dós sustenidos. / kipling recitam a plenos pulmões. / gargarejam / vidros / moídos. / o cristal dos verões", diz a poesia "As cigarras", de Sergio de Castro Pinto ${ }^{2}$. A mitologia está repleta de seres vocais. Dentre eles, e para aprofundar as questões a serem discutidas aqui, a cigarra e a formiga de Jean La Fontaine se destacam. A fábula é bastante conhecida.

${ }^{2}$ PINTO, Sérgio de Castro. Zoo imaginário, 2005, p. 20. 
Resumidamente, enquanto a formiga passa o verão trabalhando e preparando-se para o tempo de estio gelado do inverno, a cigarra gargareja a plenos pulmões (um canto que é interpretado pela racional formiga como zombaria) e aproveita a luz e o calor do sol.

0 fato é que vira-e-mexe as fabulosas personagens reaparecem, seja em peças artísticas, seja como mote filosófico, para nos lembrar de certa dicotomia existencial: enquanto uma é "amor da cabeça aos pés", a outra é pura razão. Consequentemente, esta é melhor aceita, em um mundo onde o logos foi emudecido, do que aquela. No poema de Alexandre O’Neill, por exemplo, diante da "minuciosa formiga", a cigarra canta: "Assim devera eu ser / e não esta cigarra / que se põe a cantar / e me deita a perder". Importa lembrar que, musicado por Alain Oulman e gravado por Amália Rodrigues (1969), o poema de O’Neill foi gravado por Adriana Partimpim, heterônimo de Adriana Calcanhotto, sob o título "Formiga bossa nova"3. E há ainda que se citar "Esconjuro", canção de Guinga e Aldir Blanc, cujas primeiras estrofes dizem: "A zonza da cigarra no oco do cajueiro, erê / Bota o bemol na clave do verão / Quem diz uma palavra com sentido verdadeiro, erê / Que traga um som paisagem pra canção // Falei alarido palavra de vidro / Quebrada na voz / Palavra raiada mais estilhaçada / Que o caso entre nós".

A lógica dominante - o logos desvocalizado e emudecido a serviço do gesto capital de expulsar o cantor da República platônica - leva-nos a concluir que, caso trabalhasse, a cigarra não morreria. Caso não cantasse sua própria tragédia, ela (muda e obediente) viveria mais e feliz, porque estaria segura, como a formiga. Tal ideologia, em um mundo plenamente mapeado, vigiado, assegurado, parece fazer sentido. Mas a vida será mesmo assim: tão preto, branco e muda? Por isso a importância do poema de Sergio de Castro Pinto: focando na cigarra, apagando a sua antagonista, o poema opera a valorização da vocalidade — da percepção da vida pelos pulmões, para além do cérebro. Dito de outro modo: o poema "As cigarras" sugere uma (re)vocalização do logos.

${ }^{3}$ PARTIMPIM, Adriana. Adriana Partimpim (CD). Brasil: BMG, 2004. 
Por isso também a importância, dentro de uma economia estética das vozes, a canção “Cigarra”, de Milton Nascimento e Ronaldo Bastos. Aqui se celebra a amizade entre o cantor e o trabalhador: "Porque a formiga é / A melhor amiga da cigarra / Raízes da mesma fábula”, diz o sujeito. Os versos da canção jogam com uma delicada permuta de vozes — ora tem-se a impressão de que quem fala é a formiga, ora é a cigarra - a fim de plasmar a tal amizade. Amigas e não-antagonistas das mesmas luta e alegria que é viver. Afinal, o que seria da formiga trabalhadora sem seu duplo: a cigarra que lhe canta a vida: "enche de som o ar"? "Porque ainda é inverno / Em nosso coração /Essa canção é para cantar”, diz a formiga revelando a importância do outro e tecendo uma metacanção.

Gravada algumas vezes pela cantora Simone, a canção ganha tons novos quando gravada por Milton Nascimento (a formiga: aquele que $f e z$ (trabalhou) a canção) e Simone (a cigarra: aquela que canta - e também faz - a canção), no disco Simone ao vivo ${ }^{4}$. Porque ela pediu a ele uma canção para cantar (a primeira gravação é de 1978), a formiga fez uma canção que servisse à natureza da cigarra: arrebentar-se de tanta luz e aqui entra em ação um providencial eco dos vocalizes zi, zi, zi, zi cou si, si, si, simone) fragmentando, duplicando e expandindo a festa sonora: fazendo uma personagem na outra encher de som o ar. E eis que surge o punctum da canção: a formiga precisa do canto da cigarra. Ele lhe anuncia a vida, serve de trilha sonora à uma existência destinada ao trabalho. Ouvinte e cantora se confraternizam na aceitação de suas funções complementares. E como a voz mediatizada - mesmo plugada, manipulada, modificada, alterada pelos instrumentos e suportes técnicos - indicia (revela) a voz que sai de uma garganta, eis Simone e Milton Nascimento celebrando a amizade através de uma canção amiga. Ou seja, a voz (fenômeno) do sujeito da canção só existe porque há a voz de dois indivíduos de carne e osso dando-lhe vida. E "Essa canção é para cantar / Como a cigarra acende o verão / E ilumina o ar".

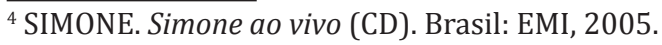


Empunhando pente (domando os cabelos desgrenhados, animalizados, geniais) e espelho (vaidades, ilusão, ficção), as sereias se forjam sensuais. Com os signos do mito já deslocados por certa ideologia urdida na Idade Média, que tem a mulher como a portadora do dom de iludir, as iaras se distanciam das tenebrosas sereias homéricas. Ou melhor, agregam ao canto irresistível, a beleza física sedutora. Esse percurso traz consequências: a mais negativa é a desvocalização do logos - um processo amparado pela "surdez" da filosofia de matriz platônica que teme os efeitos da mistura da palavra enunciada com a voz inimitável.

A sereia passa a ser sinônimo de mulher muito bonita, encantadora e fatal. Mas não perde sua ligação com mitos fundadores de criação e de proteção. É o caso de Iemanjá, Iara, Dona Janaína. Mas a sereia é, antes de tudo, a voz que relata aquilo que ouviu da musa. Para o cancionista (neo-sereia), a canção é a musa. Assim como a poesia é a musa do poeta. 0 cancionista é a sereia da sereia e, de viés, do ouvinte.

No disco Caravana sereia bloom ${ }^{5}$, a cantora Céu reposiciona o mito: injeta no imaginário do ouvinte possibilidades de apreensão do significado do termo neo-sereia. Primeiro, porque Céu é o nome sirênico (artístico, performático) de Maria Poças, um nome a serviço do cantar, uma persona cancional. Maria Poças é e não é Céu - preserva e revela intimidades de uma e da outra. Ela morre para viver com Iemanjá - arquétipo de anima. Segundo, porque a cantora está atenta à itinerância das canções. Sabe que em tempos de mobilidade pode ter seu canto acessado ao prazer do desejo do ouvinte e quer ir, indo: "O vento é um menino bulindo com a gente", canta. E terceiro porque na canção "Sereia” o sujeito diz: "Sereia do mar / Me conta o teu segredo / Do teu canto tão bonito / Prometo não espalhar". É na sereia do mar — na poesia, na canção que Céu busca os elementos de seu canto. Ao evocar a musa-sereia, Céu é aedo de acontecimentos, é neo-sereia.

É interessante notar que "Sereia" entra no disco como uma vinheta ligando canções e se revelando como o núcleo luminoso da proposta

${ }^{5}$ CÉU. Caravana sereia Bloom (CD). Brasil: Universal, 2012. 
do disco. Tocado pela sereia do mar, por dona Janaína, pela poesia, pela canção, o sujeito canta: “Sereia do mar / Também sou fruto d'água / Vim do rio doce aprender / 0 tal do canto que traz / Pra bem perto nosso bem-querer". A sereia conta aquilo que a musa ouviu e lhe contou. Ela traduz a história para os ouvidos humanos. A musa guarda o segredo (do acontecimento) sussurrado apenas ao ouvido privilegiado do poeta (do cancionista, da sereia), que compõe um canto sirênico audível ao ouvinte comum. E assim ouvimos o inaudível. Desse modo, nunca é demais distinguir Sereias e Musas.

A fim de curiosidade, vale lembrar que, como está registrado em uma das versões do mito ${ }^{6}$, ao se atreverem a competir com as Musas, as Sereias tiveram suas penas arrancadas e usadas como coroas. Filha de Mnemósine, a musa conserva o acontecimento que presenciou e que precisa ser traduzido em canção pelo poeta, cancionista. A sereia atua tanto na nossa incompetência humana no uso das palavras, quanto na nossa necessidade por canção: palavra cantada na voz de alguém. A sereia nos fornece verbo, melodia e voz. E, no caso da neo-sereia, sendo também humana, como seu ouvinte, exposta a semelhantes afetos (agrados e desagrados), é nossa cúmplice e nosso álibi. Iara irmã do indivíduo-ouvinte na existência.

A canção "Sereia" tem letra e programação da própria cancionista. Os recursos técnicos auxiliam a cancionista no ato de entoar o canto sirênico. Ecos e reverberações melódicas e vocais criam o clima sedutor, embriagante e propício ao despertar do impulso lúdico. Estas elucubrações se adensam quando obtemos a informação de que "Sereia" é dedicada a Rosa Nena, filha de Maria Poças. Rosa é a musa (a canção) que canta Céu (a cancionista) que, por sua vez, canta a musa. E são as dobras desse canto que faz Céu ser ainda menina, aproximando-se do desejo do ouvinte. "Pro ser humano, viver é pouco". Neo-sereia, Céu se enfeita com batom vermelho, porém, diferente da grande-sereia, não precisa "do espelho do retrovisor para não [se] borrar", como canta

${ }^{6}$ LAO, Meri. Las Sirenas, 1995. 
noutra canção do mesmo disco. Errante, não-divina, ela canta adornada num vestido de paetês-escamas de muitos azuis suas memórias conservadas "no sal do [meu] mar", trazendo para perto o [seu, o nosso] bem-querer.

Ao que tudo indica, quando lemos um texto em voz alta estamos mais atentos ao conteúdo dele. Enquanto que quando cantamos o que importa é a expressão daquilo que é dito (cantado). Há uma vitalidade intrínseca que diferencia a palavra falada da palavra cantada. E essa vitalidade está manifesta na voz: é representada pelo sopro de ar que atravessa o corpo e se encorpa na garganta. Obviamente, os níveis de aproximação entre um ponto e outro são tênues e frágeis. Há conteúdo no canto, assim como há expressão na leitura em voz alta. Nesta, por exemplo, o leitor, em geral, busca apresentar a trajetória do sujeito-lírico trabalhando a tessitura entoativa. E assim caímos no campo das paixões. É calcado na paixão que o leitor e/ou o cantor imprimem mais ou menos vitalidade à palavra que seus pulmões lançam no ar depois de tocar (e ser tocada por) sua garganta, úvula e impregnar-se de saliva, na boca.

As canções, deste modo, são regidas pelo sensível, que, por sua vez, é base da cognição. Pensar tais coisas exige a vocalização do logos. Exige reconhecer que nem só de escrita vive o Homem, mas também daquilo que é dito, cantado. Seja como for, há um gradiente de possibilidades entre a intenção do autor e a intenção do leitor. Para nós, é impossível falar sem fazer uso da curva melódica. Por sua vez, um cantor trabalha a dicção de cada coisa que canta, faz escolhas e explora intensidades acelerações, desacelerações.

Como mensurar a importância da leitura em voz alta à cultura e à construção de conhecimento, quando o acesso ao mundo da escrita era mais restrito? E até que ponto o leitor (sua voz: escolhas entoativas) interferiu na transmissão? Quão fundamentais são as histórias lidas às 
crianças? Isso sem contar as decisivas canções de ninar. Ou seja, na canção (na materialidade da canção) o que determina sua eficácia é o modo de dizer da voz, mais do que o que é dito (o texto). É preciso analisar significantes e significados, a textura melódica, as pausas, a respiração. A vitalidade impressa na canção para chegar a alguma significação possível. E saber de onde vem a canção.

Guardado no disco $C h a ̃ o^{7}$, o sujeito da canção "De onde vem a canção", de Lenine, age atravessado pela pergunta-título. Sem resposta definitiva, mas cheio de suspeitas e afetos, ele recolhe instantes - "Quando do céu despenca / quando já nasce pronta / quando o vento é quem venta / (...) / Quando se materializa / No instante que se encanta / Do nada se concretiza" - a fim de empreender sua busca. Colocar-se no meio.

Investigar de onde vem e para onde vai a canção — "Quando tudo silencia / Depois do som consumado" — é investigar a condição do Humano. 0 sujeito sugere, já que pergunta afetado pela canção, que ela vem e vai para dentro. Afinal, é quando finda que de fato a canção começa a ser processada em nós: entra para a nossa memória sonora - definidora daquilo que somos. Cantor, Lenine joga com a perspectiva de que a canção só é canção quando não é mais sua (do autor, leitor, cantor): "quando nasce pronta, quando se propaga, quando se irradia" é que ela é ela - faz o vento ventar, no instante que se encanta.

Por outro lado, o sujeito criado por Lenine traz à tona a intuição como fator determinante para a definição da canção como linguagem. No Brasil, pelo menos. Nem músico, nem poeta de formação escolar: cancionista - agente da intuição vitalizada, da compatibilização intuitiva entre letra e melodia. Intuindo e cantando, o sujeito de "De onde vem a canção" questiona sua posição no mundo e averigua - trabalhando sobre uma linha melódica sem falso apogeu — os modos de proceder e ser da canção. Sem saber de onde ela vem, o sujeito a canta. Sem saber de onde veio e para onde vai, o homem vive. E canta para manter-se encantado.

${ }^{7}$ LENINE. Chão (CD). Brasil: Universal, 2011. 
No livro Vozes plurais - Filosofia da expressão vocal Adriana Cavarero investiga como a filosofia tem trabalhado na promoção da própria "surdez", à deriva dos cancionistas, poetas e filósofos que investem no apuro do ouvido. Para a autora, agindo deste modo, a filosofia nega a unicidade de cada voz, negando por sua vez a especificidade de cada indivíduo. Cavarero anota que "a voz de quem fala é sempre diversa de todas as outras vozes, ainda que as palavras pronunciadas fossem sempre as mesmas, como acontece justamente no caso de uma canção"8. Cantar apresenta a verdade de um vocálico - "é ter o coração daquilo" — e isso desestabiliza as formas generalizadoras - "universalidades abstratas e sem corpo" - do modo como temos desenvolvido o pensamento. No Brasil, não é à toa que "nossa gente era triste amargurada, inventou a batucada pra deixar de padecer", como diz a canção de Assis Valente, dando uma amostra daquilo que uma cultura híbrida, mestiça e miscigenada como a latino-americana pode oferecer ao mundo em contribuição ao pensamento. Talvez isso explique em parte não termos aqui uma escola filosófica forte frente às culturas hegemônicas e tenhamos desenvolvido o ensaio como espaço de reflexão daquilo que (possivelmente) somos.

Cantando juntos mandamos a tristeza embora. Aquela tristeza que quer tomar conta do sujeito da canção "Filosofia”, de Noel Rosa - “O mundo me condena, e ninguém tem pena / Falando sempre mal do meu nome / Deixando de saber se eu vou morrer de sede / Ou se vou morrer de fome" -, e que logo cede lugar a outra afirmativa: "Não me incomodo que você me diga / Que a sociedade é minha inimiga / Pois cantando neste mundo / Vivo escravo do meu samba, muito embora vagabundo". Movido por uma filosofia íntima, alicerçada no seu jeito de corpo, o sujeito vai da defesa autopiedosa ao ataque: "Quanto a você da aristocracia / Que tem dinheiro, mas não compra alegria / Há de viver eternamente sendo escrava dessa gente / Que cultiva hipocrisia".

"É, por assim dizer, a phoné que determina a fisiologia do pensamen-

${ }^{8}$ CAVARERO, Adriana. Vozes plurais: filosofia da expressão vocal. 2011, p. 18. 
to"' ${ }^{\prime \prime}$ como diria Cavarero. Pensar com o corpo inteiro, a plenos pulmões, não com o cérebro. Livre das amarras que o dinheiro impõe, artista, cantor, sambista, o sujeito da canção exalta a alegria, que, por sua vez, não denega a dor. Cantada por Mart'nália no disco Pé do meu samba ${ }^{10}$, "Filosofia" ganha valores novos. Afinal, quem melhor do que uma mulher que guarda em si - voz e corpo — os signos do malandro (fingidor, malabarista) para cantar os emblemas de uma nova filosofia? Aqui, corpo e palavra cantada mostram como o logos perdeu a voz, a escuta. E se empenham na vocalidade do sujeito afastado das ideias gerais, platônicas. Há, portanto, uma sabedoria singular na voz do sujeito de "Filosofia": cantar é estar vivo, pensar a plenos pulmões. Lúcido de sua condição (humana) de escravo, através da voz o sujeito faz a sua escolha entre o samba e a hipocrisia: forja uma verdade. Como Adriana Cavarero atesta: "A voz, qualquer coisa que diga, comunica antes de tudo, e sempre, uma só coisa: a unicidade de quem a emite".

\section{$* * *$}

Como sabemos, mitologicamente a poesia (o logos poético) está ontologicamente imbricada à musicalidade, ao ritmo da vocalização das palavras. Convenientemente, o corte acontece no Renascimento, momento de radicalização do longo processo filosófico de desvocalização do logos.

Capturando a phoné no sistema da significação, a filosofia não só torna inconcebível um primado da voz sobre a palavra como também não concebe ao vocálico nenhum valor que seja independente do semântico. Reduzida a significante acústico, a voz depende do significado. Longe de ser óbvia, essa dependência é fundamental. Ela aprisiona a voz num sistema complexo que subordina a esfera acústica à visual. (CAVARERO: 2011, p.52).

É também Cavarero (Idem. p.50-51) quem registra:

${ }^{9}$ Idem, p. 37.

${ }^{10}$ MART’NÁLIA. Pé do meu samba (CD). Brasil: Universal, 2002. 
A matriz etimológica é conhecida. Logos deriva do verbo legein. Desde a Grécia arcaica, este verbo significa tanto 'falar' quanto 'recolher', 'ligar', 'conectar'. Isso não é surpreendente, uma vez que quem fala liga as palavras umas às outras, uma após a outra, recolhendo-as em seu discurso. Tampouco é estranho que, exatamente por isso, legein signifique também 'contar' e, ainda mais propriamente, 'narrar'. Na sua acepção comum, o logos se refere à atividade de quem fala, de quem liga os nomes aos verbos e a qualquer outra parte do discurso. 0 logos consiste essencialmente numa conexão de palavras. Justamente nesse plano da conexão, que 'liga' e 'recolhe' segundo determinadas regras, está centrada a atenção da filosofia. Centrada inclusive com prejuízo - mas talvez fosse melhor dizer: sobretudo com prejuízo - do plano acústico da palavra. 0 logocentrismo filosófico se interessa, principalmente, pela ordem que regula a conexão, isto é, pela linguagem como sistema da significação.

Felizmente, parte importante dos pensadores, entre eles Adriana Cavarero, vem questionando os paradigmas de base platônica de desvocalização do logos. 0 ponto central da questão não é a desvalorização da escrita, ou sua negação, mas observar os contatos, as intersecções e os pontos de mutação entre a palavra falada e a palavra escrita. Importa ouvir o logos não para "entendê-lo" (racionalmente), mas para a partir dele escolher caminhos. Ou seja, questionar a ordem que regula a conexão entre as palavras e se deixar envolver com a "força bruta": ser criação ao ritmo do plano acústico da palavra.

Quando dizemos que o som era sentido, sua força era de tocar o homem para qualquer lugar e não de fazer o homem refletir sobre este fenômeno, dividi-lo ou analisá-lo. Assim, a gestualidade espontânea do corpo é já por si mesma certa objetivação, uma certa manifestação do sentido. Ela não é, obviamente, a objetivação de uma ideia, mas a de uma situação no mundo sobre a qual se decalcam as próprias ideias. (TOMÁS: 2002, p. 50).

É por isso que a proposta do meu trabalho passa por um retorno mitológico do vocalizar, do cantar, do narrar: por reconhecer aqui que a 
sonoridade das palavras tem mais relevância do que seus significados. Ou melhor, que o plano acústico da palavra está visceralmente ligado à significação empreendida pelo ouvinte. Daí também que um livro como Milagrário pessoal, de Jose Eduardo Agualusa, ajuda na argumentação de minha intenção. Temos no livro de Agualusa (2010, p.15) o embate entre um professor e uma ex-aluna (Iara), linguista, cujo trabalho é identificar e dicionarizar as palavras novas.

A Iara interessam, sobretudo, as palavras recém-nascidas, ainda úmidas, ofegantes, indefesas, caídas de repente nesse vasto alarido que é a vida. Para encontrar eventuais neologismos serve-se de um programa informático, o Neotrack, o qual recolhe, a partir dos jornais do dia disponíveis na internet, as palavras não dicionarizadas.

Fazendo uso de uma escrita que utiliza o ritmo da fala, posto que a "sensação" criada é a de uma conversa entre narrador e leitor, Agualusa tematiza a complementaridade entre a fala e a escrita. 0 narrador se dirige diretamente ao leitor, bem como faz avanços e recuos no tempo, suspensões da narrativa para inserir outras histórias, num procedimento típico da oralidade. Iara entra em conflito quando percebe a disseminação inesperada de um grande número de neologismos. E busca a ajuda do antigo professor para entender o problema. Em geral, personagens femininas são o motor dos romances de Agualusa, na contramão de certa corrente que silencia as mulheres que cantam.

Referência indígena brasileira, em Milagrário pessoal (Idem, p.16-17) Iara, para além da personagem, mas mimetizada ao narrador, é a sereia que seduz o leitor a ouvir o som das palavras:

Até esta altura qual foi o neologismo mais bonito que tu encontraste? Iara esperava a pergunta: Não sei, rendeu-se. Nunca me apareceu uma palavra bonita. Mesmo bonita. A verdade é que os neologismos são quase todos feios. Acho-os, de uma forma geral, grosseiros e enfadonhos. 
Mais adiante, quando instigada a escolher as dez palavras mais bonitas da língua, Iara sugere que é a sonoridade o que as tornam bonitas e grávidas de significado.

A indicação de Iara como sereia, gesto de recuperação, apropriação e manipulação do mito feito por Agualusa durante todo o romance, está presente já na capa do livro. Tanto na edição portuguesa - fotografia de uma imagem de Iara em local de devoção, quanto na brasileira - fotografia “A Sereia e o Cinema”, still do vídeo Psinoe, de Adriana Varejão. Seja como for, a sereia amazônica Iara imprime sua mitopoética no imaginário da língua portuguesa-brasileira e se espalha pelas artes. De José de Alencar (O tronco do ipê) ao grupo Axial ("Beijo da Iara”, de Kiko Dicucci), passando por Olavo Bilac ("Iara"), que descreve a sereia indígena:

Vive dentro de mim, como num rio, Uma linda mulher, esquiva e rara, Num borbulhar de argênteos flocos, Iara De cabeleira de ouro e corpo frio.

Entre as ninfeias a namoro e espio:

E ela, do espelho móbil da onda clara, Com os verdes olhos úmidos me encara, E oferece-me o seio alvo e macio.

Precipito-me, no ímpeto de esposo, Na desesperação da glória suma, Para a estreitar, louco de orgulho e gozo...

Mas nos meus braços a ilusão se esfuma: E a mãe-d'água, exalando um ai piedoso, Desfaz-se em mortas pérolas de espuma.

A título de mais um exemplo, na canção "Kirimurê", de Jota Velloso, ela é a sereia que canta a afirmação da existência de um povo que foi dizimado - "Onde era mata hoje é Bonfim / De onde meu povo espreitava baleias / É farol que desnorteia a mim" - e da certeza da permanência do desejo de ser os donos daqui: "Se me der a folha certa / E eu cantar 
como aprendi / Vou livrar a Terra inteira / De tudo que é ruim". Sabe-se que a região que hoje conhecemos como Baía de todos os santos era chamada pelos tupinambás de Kirimurê. Na voz de uma Maria Bethânia ${ }^{11}$ mimetizada em Iara, a canção ganha sentidos amplos: "Espelho virado ao céu / Espelho do mar de mim / Iara índia de mel / Dos rios que correm aqui / Rendeira da beira da terra / Com a espuma da esperança (...) Na fome da minha gente / E nos traços que eu guardo em mim / Minha voz é flecha ardente / Nos catimbós que vivem aqui”.

Assemelha-se a essa "Iara índia de mel”, a cantada pelo grupo Axial em "Beijo de Iara"12. Ambas são concentração de doçura e resistência, "espelho virado ao céu" a refletir no ouvinte que a escuta a beleza de seu canto beira-rio. Diz o sujeito da canção: "Ouvi no beira-rio / um canto ecoar / é a mãe d'água / pra me encantar". Senhora das águas ou Mãe -d'água, a mitopoética de Iara é contada vocalmente e passa gerações. 0 sujeito da canção recolhe e condensa algumas narrativas sobre a sereia. Nos versos "Rema rema remador / Iara quer te namorar / quem provar dos beijos seus / com a morte vai se casar", temos tanto a retomada da cantiga folclórica "Rema rema remador, que este barco é do Senhor", quanto da marchinha "Marcha do remador": "Rema, rema, rema, remador / Quero ver depressa o meu amor / Se eu chegar depois do sol raiar / Ela bota outro em meu lugar". No encontro dos fragmentos das canções permanece o mote de não sucumbir ao canto mortal.

Mas está no modo de apresentação da canção por Sandra Ximenez (vocais e piano elétrico), Felipe Julián (loops, ruídos e teclados) e Leonardo Muniz Corrêa (clarinete) o engenho do encanto. 0 clima sonoro criado pelo grupo presentifica a mítica sereia. 0 palimpsesto cultural brasileiro, onde Iara se forja, é apontado na palheta de sons do grupo Axial. E assim o feitiço se realiza: "Espelho virado ao céu / Espelho do mar de mim / Iara índia de mel / Dos rios que correm aqui", como canta

\footnotetext{
${ }^{11}$ BETHÂNIA, Maria. Mar de Sophia (CD). Brasil: Biscoito Fino, 2006.

12 Projeto Axial. Simbiose (CD). Brasil: 2011. Disponível em: http://www.axialvirtual. com/Axial/Axial/encarte_\%5BCD_SiMBiOSE\%5D.html
} 
Bethânia. Ou: "Sinhá sereia chegou / beldade maior / nunca se viu // Deixa eu banhar você / lavar teus cabelos / nas águas do rio".

O grupo Axial e Maria Bethânia mostram que a potência da palavra está em sua vocalização. É assim também que age o narrador de Agualusa: logos vocalizado, quente e úmido na voz de alguém cantando. "O corpo aí se recolhe. É uma voz que ele escuta e ele reencontra uma sensibilidade que dois ou três séculos de escrita tinham anestesiado, sem destruir", como observaria Paul Zumthor ${ }^{13}$. Surge o beijo. Da Iara.

\section{$* * *$}

Em A pele que habito, filme de Pedro Almodóvar, a jovem Norma (Ana Mena), brincando distraidamente no jardim, cantando os versos de "Pelo amor de amar", de José Toledo e Jean Manzon, desperta a mãe marcada por um incêndio que lhe desfigurou o corpo. Em uma torção mítica feliz, a filha é a sereia da mãe. A voz de Norma — suas inflexões infantis, seu esforço para cantar em português uma canção de ninar desnaturada dá o sopro de vida que Gal (a mãe) necessita. "O coração do mundo canta no meu coração / Meus pés seguem sozinhos a dançar / Eu não conheço em mim a grande dor da solidão / Se em tudo eu encontro o dom de amar", canta. E ao mesmo tempo, é essa a voz que também direciona a personagem à luz, a ver-se refletida em sua aparência aterradora, ao fim trágico e irrefutável. Desse modo, a voz do coração da criança é o veneno -remédio de Gal. "Só a morte apazigua esse nada-mais-tem-sentido que a decrepitude nos sussurra a todo instante. Canto de sereia às avessas convencendo Ulisses de que o mar secou", anotaria o narrador do livro Minha mãe se matou sem dizer adeus, de Evandro Affonso Ferreira ${ }^{14}$.

As consequências do gesto de furtar da mãe o papel de sereia definirá a existência da filha. E a trama de Almodóvar. Mais tarde, a audição da mesma canção, agora em espanhol e na voz de Buika (uma cantora pro-

\footnotetext{
${ }^{13}$ ZUMTHOR, Paul. Performance, recepção, leitura, 2007, p. 60.

${ }^{14}$ FERREIRA, Evandro Affonso. Minha mãe se matou sem dizer adeus, 2010, p. 45-46.
} 
fissional), arrastará a filha ao destino. "Pelo amor de amar / Quero ser a luz que sorrir na flor / Pelo dom de amar / Quero ser a flor que se deu de amor", encerra a canção gravada por Ellen de Lima em 1960 para o filme os bandeirantes, de Marcel Camus.

Concluímos que somos alguma coisa feita para ser cantada. E cantante. Sustentamo-nos na voz. Mas não é qualquer canção. E, principalmente, não é qualquer voz. A voz que (me) canta é a voz que governa (meus) mundos. Em geral, pela nossa trajetória histórica e genética, pensamo-nos (nós: latino-americanos) com o corpo todo (homo ludens pulsando), e a voz tem presença decisiva nesse processo, como uma resposta intuitiva ao raciocínio colonizador, posto que a voz convida ao movimento: à dança.

"Nunca fomos catequizados, fizemos foi carnaval", diria Oswald de Andrade. A palavra escrita nunca foi suficiente para nós, brasileiros, latino-americanos. 0 empenho da palavra falada sempre teve mais valor do que o da palavra escrita. Muito embora, em um gesto típico de cópia mal sucedida e subalterna, tenhamos burocratizado em excesso nossos pensamentos e palavras, atos e omissões. Mais do que quaisquer outros povos, estamos melhor preparados, porque fundamo-nos sobre os atos de criar e conectar-se, para viver o mundo contemporâneo. 0 jeitinho é nosso veneno-remédio, nossa sereia a nos arrastar à vida (empurrar para frente) e à morte.

Digo tudo isso para destacar a beleza da voz de Jussara Silveira cantando "A voz do coração", de Celso Fonseca e Ronaldo Bastos, no disco Ame ou se mande (2011). Há nas inflexões vocais de Jussara - nas nuances sutis nas alturas melódicas - um descompromisso (natural e espontâneo) com aquilo que é dito. Voz que luta eroticamente com uma melodia em soluços, compassada. Já tendo sido gravada por Celso Fonseca, com Jussara Silveira "A voz do coração"15 ganha contornos sirênicos sedutores. Jussara e sua voz nos arrastam para um campo onde somos amor da cabeça aos pés: desperta em nós a nostalgia da pura interioridade. Semelhante à criança que desperta a mãe.

${ }^{15}$ SILVEIRA, Jussara. Ame ou se mande (CD). Brasil: Joia moderna, 2011. 
“Quem poderá em vão calar / a voz do coração?". A pergunta inicial do sujeito parece querer refletir a nossa dúvida humana. Entre a razão (o logos desvocalizado) e a emoção (a vocalização do saber) o coração canta como contrapartida estética ao abandono - "Se o amor quiser partir num dia de manhã sem avisar". É esta voz que dita o rumo a ser seguido pelo sujeito cantor da canção. Fazer do limão uma limonada, da solidão um amor em paz, equilibrar dor e alegria no estético - na criação - são ensinamentos vindos do coração. A voz de alguém cantando anuncia que há um ser único e de carne e osso vibrando-lhe no ar. Ao contrário da outra "canção de fossa", porque ao invés de pensar em causas e efeitos, criou, transcriou tudo em canto, o sujeito decreta: "Meu mundo não caiu preciso lhe falar / eu gosto de você demais // Preciso lhe dizer de todo o coração / a falta que você me faz". Precisa e diz.

Sem o outro que lhe abandonou, o sujeito não cantaria. É nisso que ele foca, cantando para mandar a tristeza embora, ou melhor, para hibridizá-la à alegria e uni-las no canto necessário à vida, em um exercício de criatividade desprendido da carga pesada que é viver. Aqui, a voz poética (da memória, do coração, em certa medida) é o estabilizador - sem ela o ser humano não suportaria estar vivo. Dando vida a este sujeito cantante, Jussara Silveira, tal e qual a personagem Norma de Pedro Almodóvar, coloca-nos diante do espelho: é a sereia que promove o movimento, convida-nos à criação. E ao final, como diria o sujeito de "Ilusão à toa", de Johnny Alf: "Meus olhos sentem / Minhas mãos transpiram / É um amor que eu guardo há muito / Dentro em mim / E é a voz do coração que canta assim / Assim”. E “quem poderá em vão calar seu coração?”.

$* * *$

São vários e complexos os caminhos que levam à musicalização de um texto escrito. Sabemos que as palavras tem "musicalidade", mas esta só é efetivada na voz, na vocalização da palavra. Sentimos esta musicalidade, já devidamente naturalizada dentro de nós, ao ler silenciosamente um 
texto porque estamos infectados pela memória sonora da palavra falada (cantada), pela sua materialidade vocal. Encontrar a gestualidade vocal exata, equilibrar texto e música na voz para "melhor dizer" uma mensagem é tarefa árdua e prazerosa enfrentada pelo cancionista. 0 certo é que se não há um "jeito único" de vocalizar um texto, cabe ao destinador esquentá-lo de modo a transmitir a mensagem da melhor forma possível à compreensão do destinatário. Do mesmo modo como fazemos ao falar. Ou seja, as "mesmas palavras" servem a intenções diversas e para diferenciar as intenções a voz entra em ação. Quando lemos um texto, entre outros artifícios, os sinais oferecidos pelo narrador são o que nos auxilia a distinguir as intenções.

Caetano Veloso, por exemplo, opta por uma cama sonora passional para musicar/vocalizar um trecho do livro Minha formação, de Joaquim Nabuco, incentivado pela constatação do narrador que diz: "A escravidão permanecerá por muito tempo como a característica nacional do Brasil"16. Ao falar sobre a permanência fantasmagórica da escravidão como algo introjetado ao jeito de ser do brasileiro, entre lembranças, saudades e afirmações, o cancionista recusa qualquer gesto que nublaria sua introspecção, sua reflexão interna sobre o caso. "É ela o suspiro indefinível que exalam ao luar as nossas noites do norte"17, Caetano Veloso finaliza vocalmente melancólico para plasmar a melancolia do sujeito da canção, do narrador de Nabuco.

Dito isso, podemos começar a entrar no entendimento da proliferação de sons com a qual Iara Rennó presenteia o ouvinte do disco Macunaíma Ópera Tupi ${ }^{18}$ (2008). Tradução intersemiótica do livro Macunaíma - o herói sem nenhum caráter, o disco de Iara musica e vocaliza trechos levando o ouvinte a empreender uma viagem etno-antropo-semio-musicológica tal e qual a organizada pelo musicólogo Mário de Andrade na seminal Missão de Pesquisas Folclóricas. 0 disco é o resultado das ano-

\footnotetext{
${ }^{16}$ NABUCO, Joaquim. Minha formação, 1999, p. 232.

${ }^{17}$ Idem.

${ }^{18}$ RENNÓ, Iara. Macunaíma ópera tupi (CD). Brasil: SENAC, 2008.
} 
tações afetivas a partir da leitura de Iara sobre o livro. Notas sobre notas, somos convidados a navegar com Macunaíma pela diversidade do Brasil sonoro. Turistas aprendizes que somos. Justapondo música erudita e música folclórica, bem como funk, eletrônico, sem juízos de valor, mas pelo prazer do gesto brasileiro, o disco explicita o vigor plural e étnico do país. E o conjunto resulta em ritual sincrético: violino e tambor, eletrônico e cordel, psicodelia e cantigas folclóricas, o Tupi e o alaúde. Embolada, repente, rap. Difícil definir. Melhor sentir e reconhecer na (pro) fusão os rascunhos de Brasil.

Ao extrair do livro reconhecidamente importante ao cânone literário brasileiro os trechos e versos que compõem as canções do disco, Iara promove, via instinto caraíba, a valorização da antropofagia como signo estético e artístico. Além de devolver às palavras a vocalização contida nelas antes de Mário de Andrade as fixar no papel. Iara revocaliza lendas, mitos e rituais indígenas, africanos e portugueses com a mesma perspicácia rapsódica engendrada pelo autor do livro. E, assim, a “ópera tupi", a "odisseia” de Mário se (re)traduz em veículo da tradição vocal e popular. Como o autor anota ao final do livro: "Me acocorei em riba destas folhas, catei meus carrapatos, ponteei na violinha e em toque rasgado botei a boca no mundo cantando na fala impura as frases e os casos de Macunaíma, herói da nossa gente"19.

Traindo a tradição para manter a beleza da tradição, Iara copia, recorta, cola, mistura a "fala impura". Vejamos o exemplo de "Bamba querê". A canção incorpora a cadência das aliterações presentes no texto de tal modo que fica difícil para o ouvinte imaginar outra rítmica senão a criada e inventada por Iara. É na dança do orixá Iemanjá no terreiro que Iara se mira para construir a canção e plasmar a imagem do cavalo possuído diante do ouvinte.

Iara Rennó antologiza, em tom mario-andradiano, exatamente os versos vocalizados para montar a canção "Bamba querê”. A querência de Iara desterritorializa, remelexe, bambeia extratos sonoros para (re)

${ }^{19}$ ANDRADE, Mario de. Macunaíma o herói sem nenhum caráter, 1988, p.129. 
apresentá-los encapsulados em forma de uma canção una, núcleo duro do país de semiologia macunaímica. E, assim como Haroldo de Campos anotou sobre o livro, "no coquetel, porém, havia método"20, no canto de Iara — ou seria da Iara (sereia)? — há a aplicação do método daquilo que podemos chamar, juntos com José Celso Martinez Corrêa, de "macumba antropofágica". Desse modo, a "linhagem rabelaisiana" presente no livro é restaurada por Iara na canção, no disco: do cruzamento de várias sintaxes ao protagonismo da voz, passando pelo além do bem e do mal nietzschiano.

\section{Referências bibliográficas}

AGUALUSA, J. E. Milagrário pessoal. Rio de Janeiro: Língua Geral, 2010. ANDRADE, M. Macunaíma o herói sem nenhum caráter. Belo Horizonte: Itatiaia, 1988.

CAMPOS, H. Morfologia do Macunaíma. São Paulo: Perspectiva, 1973. CAVARERO: A. Vozes plurais: filosofia da expressão vocal. Belo Horizonte: Editora da UFMG, 2011.

FERREIRA, E. A. Minha mãe se matou sem dizer adeus. Rio de Janeiro: Record, 2010.

LAO, M. Las Sirenas. México: Ediciones Era,1995.

NABUCO, J. Minha formação. Rio de Janeiro: Topbooks, 1999.

PINTO, S. C. Zoo imaginário. São Paulo: Escrituras Editora, 2005.

TOMÁS, L. Ouvir o logos: música e filosofia. São Paulo: Editora UNESP, 2002.

ZUMTHOR, P. Performance, recepção, leitura. São Paulo: Cosac Naify, 2007.

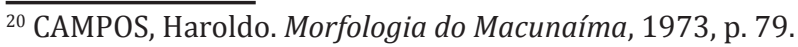

